\title{
Evaluation of somatic embryo production during embryogenic tissue proliferation stage using morphology, maternal genotype, proliferation rate and tissue age of Pinus thunbergii Parl
}

\author{
Tingyu Sun ${ }^{1,2}$ ' Yanli Wang ${ }^{1,2} \cdot$ Lihua Zhu $^{1,3}$. \\ Xiaowei Liu ${ }^{1} \cdot$ Qingtong Wang $^{1} \cdot$ Jianren Ye $^{1,3}$
}

Received: 26 October 2020 / Accepted: 10 December 2020 / Published online: 27 May 2021

(C) The Author(s) 2021

\begin{abstract}
To determine the optimal embryogenic capacity (somatic embryo production) of the selected elite nematoderesistant genotypes of Pinus thunbergii, variables such as embryogenic tissue (ET) morphology, maternal genotype, proliferation rate and tissue age were analyzed. ET morphology and histological evaluation of the proliferation stage showed a decrease in filamentous clump and protuberant surfaces and a decline in the acetocarmine-staining area, which indicates a decrease in somatic embryo production (SEP). Variations in cell physiology during the proliferation stage showed that SEP was positively correlated with soluble sugars and proteins, but negatively correlated with
\end{abstract}

Project funding: The work was supported by the National Key Research and Development Projects (2018YFD0600203, 2017YFD0600104), the Priority Academic Program Development of Jiangsu Higher Education Institutions (PAPD), andDoctorate Fellowship Foundation of Nanjing Forestry University.

The online version is available at http://www.springerlink.com

Corresponding editor: Tao Xu

Supplementary Information The online version contains supplementary material available at https://doi.org/10.1007/ s11676-021-01311-1.

Jianren Ye

jrye@njfu.edu.cn

1 College of Forestry, Nanjing Forestry University, Nanjing 210037, Jiangsu, People's Republic of China

2 Jiangsu Key Laboratory for Prevention and Management of Invasive Species, Nanjing Forestry University, Nanjing 210037, Jiangsu, People's Republic of China

3 Collaborative Innovation Center of Sustainable Forestry in Southern China, Nanjing Forestry University, Nanjing 210037, Jiangsu, People's Republic of China starch, peroxidase, and superoxidase. In addition, SEP was significantly $(p<0.001)$ affected by maternal genotype, tissue age and proliferation rate. Moreover, SEP was positively correlated with proliferation rate $(r=0.98, p<0.001)$, but negatively correlated with tissue age $(r=-0.95, p<0.001)$. In general, the results suggest that SEP could be assessed in ET proliferation stages by the apparent cell morphology, histology, proliferation rate and tissue age, which provides novel insights for evaluating the ET maturation capacity (number of somatic embryos) during the proliferation stage of $P$. thunbergii somatic embryogenesis.

Keywords Somatic embryo production - Cell physiology $\cdot$ Cell morphology $\cdot$ Pinus thunbergii

\section{Introduction}

Somatic embryogenesis may be used as a tool to increase the quality and productivity of elite genotypes. Many efforts have been made to optimize somatic embryogenesis systems (Jones and van Staden 2001; Finkelstein et al. 2008; Herve et al.2013; Jain and Gupta 2018); however, for many Pinus species, maturation with high somatic embryo yields is an important limiting factor for practical applications (Yildirim et al. 2006; Klimaszewska et al. 2011). Similarly, somatic embryogenesis of Pinus thunbergii Parl. has been reported since 1999, but not implemented on a commercial scale (Maruyama and Hosoi 2016). One of the major limiting factors for commercial application of somatic embryogenesis is the poor maturation efficiency (quantity of cotyledonary somatic embryos per gram fresh mass [SEs g ${ }^{-1} \mathrm{FW}$ ]) (Lelu-walter and Paques 2009; Song et al. 2018). In this study, we evaluated somatic embryo 
production during the embryogenic tissue proliferation stage and established early-stage indicators to select highyielding cell lines for practical applications. These indicators were beneficial in improving the maturation efficiency of elite trees, especially for pine wood nematode-resistant $P$. thunbergii. Maruyama et al. (2005) reported a protocol for somatic embryogenesis of $P$. thunbergii, and, our group established a somatic embryogenesis protocol for $P$. thunbergii resistant to pine wood nematode and selected a maturation medium that was optimal for most cell lines of pine wood nematode-resistant $P$. thunbergii (Sun et al. 2019a, b). However, our ability to predict the performance of selected elite embryogenic tissue (ET) or maturation capacity during early stages was still limited. Krajnakova et al. (2009) reported embryogenic mass proliferation was negatively correlated with somatic embryo production (SEP). However, a positive correlation between embryogenic mass growth and SEP was reported in stone pine (Carneros et al. 2017). In addition, correlations between ET morphology and SEP have been reported. For example, ET surfaces that have a "spiky" morphology (like the filamentous and protuberant surfaces of ETs in our study) are more productive than those having smooth surfaces (Ramarosandratana et al. 2001). Additionally, ET characterized by special morphology (embryonal-suspensor mass [ESM] structures) produced the greatest maturation yield in Pinus species (Breton et al. 2005; Vestman et al. 2010). These traits can be used to assess the ET maturation capacity before the maturation process of somatic embryogenesis. Bradai et al. (2016) considered genotype a key factor that determines the quantity of SEs present during the maturation stage. Gahan and George (2008) reported that although regulatory mechanisms controlling regeneration became inoperative during subcultures, the genotype of embryonal cells did not essentially change. In contrast, Park et al. (2011) found that the embryogenic capacity and DNA content in the nucleus decreased during prolonged maintenance. In general, the genotype has to be carefully chosen because not all ETs grow well in culture (Montalban et al. 2012; Zhang et al. 2014; Malik et al. 2020). In addition, whether the maturation of SEs is correlated with morphological development and intracellular communication has also been considered (Godel-Jedrychowska et al. 2020). For practical applications, the selection of a suitable ET with high-yielding somatic embryos (SEs) during early stages is needed. Here, we studied the effects of ET morphology and physiology, maternal genotype, tissue age and proliferation rate on the SEP of $P$. thunbergii, and we established criteria to predict the ET maturation capacity before maturation of the somatic embryo. The aim was to select the ET having high-yielding SEs in the proliferation stage for practical applications.

\section{Materials and methods}

\section{Plant material}

Immature cones were collected from the pine wood nematode-resistant $P$. thunbergii in an experimental field at Nanjing Forestry University (Jiangsu, China). The mother trees were open-pollinated in a seed orchard. Tissue cultures were started in 2015 and 2016 (Sun et al. 2015; Wang et al. 2019). The immature cones were stored at $4{ }^{\circ} \mathrm{C}$ for 1 week, then female gametophytes were selected. The female gametophytes contained immature zygotic embryos when the explants were transplanted onto the initiation medium. The initiated ETs (cell lines) were transferred onto maintenance medium and numbered. The cell line number comprised the ET initiation time, seed family and clone, with the first two numbers representing the ET induction time (year after 2000), the last two numbers representing the seed family, and the number after the dash representing the clone. In this experiment, 12 established cell lines were used in total. Five selected ETs or cell lines (a clump of ET about $1 \mathrm{~cm}$ in diameter) were transferred onto maintenance medium in each Petri dish. The ETs were subcultured on maintenance medium every 2 weeks. The maintenance medium was DCR basic medium (Gupta and Durzan 1985), supplemented with $250 \mathrm{mg} \mathrm{L}^{-1}$ 2-(4-morpholino) ethanesulfonic acid (MES), $15 \mathrm{~g} \mathrm{~L}^{-1}$ maltose, $1 \mathrm{~g} \mathrm{~L}^{-1}$ myo-inositol, $500 \mathrm{mg} \mathrm{L}^{-1}$ casein acid hydrolysate, $500 \mathrm{mg} \mathrm{L}^{-1} 1$-glutamine (filter-sterilized), $5.4 \mathrm{~g} \mathrm{~L}^{-1}$ agar and plant growth regulators 2, 4-dichlorophenoxyacetic acid at $1 \mathrm{mg} \mathrm{L}^{-1}$ and kinetin at $0.1 \mathrm{mg} \mathrm{L}^{-1}$. Before sterilization, the $\mathrm{pH}$ of all media was adjusted to 5.8 and autoclaved $\left(121^{\circ} \mathrm{C}, 20 \mathrm{~min}\right)$.

\section{Maturation of somatic embryos}

The suspension culture before the maturation process was prepared according to previous reports (Sun et al. 2019b). Briefly, the suspension cultures were initiated by transferring $1 \mathrm{~g}$ ET to $30 \mathrm{~mL}$ of liquid proliferation medium in $100 \mathrm{~mL}$ Erlenmeyer flasks that were subsequently placed on an orbital shaker at $90 \mathrm{rpm}$. After 7 days of subculturing, the suspension cultures $(2 \mathrm{~mL})$ were spread onto the top of a stack of five pieces of sterilized filter paper. After the liquid medium was absorbed, the filter paper containing the cultures was placed on the surface of the solidified medium for embryo maturation. Approximately $500 \mathrm{mg}$ of ET was transferred to each Petri dish. The previously described maturation medium is able to support most cell lines of $P$. thunbergii that are resistant to the pine wood nematode (Sun et al. 2019a). Briefly, the maturation medium was an LP basic medium (Gupta and Durzan, 1987), supplemented with $2 \mathrm{~g}$ $\mathrm{L}^{-1}$ activated charcoal, $1 \mathrm{~g} \mathrm{~L}^{-1}$ myo-inositol, $1.5 \mathrm{~g} \mathrm{~L}^{-1}$ l-glutamine (filter-sterilized), $3.5 \mathrm{~g} \mathrm{~L}^{-1}$ phytagel (Sigma-Aldrich, 
St. Louis, USA), $30 \mathrm{~g} \mathrm{~L}^{-1}$ maltose, $10 \mathrm{mg} \mathrm{L}^{-1}$ abscisic acid and $125 \mathrm{~g} \mathrm{~L}^{-1}$ PEG8000. The ET was maintained in the dark at $25 \pm 1{ }^{\circ} \mathrm{C}$ for 10 weeks. After 10 weeks of culturing (without interval), the mature SEs (cotyledon embryo stage) were moved from maturation to germination medium, and the number of mature SEs was recorded. Then, the number of mature SEs per gram fresh mass (SEP) was calculated. The SEP was used as the criterion for evaluating the maturation capacity of the ET.

\section{Maturation experiment 1: morphology and histological development}

\section{Morphology characteristics}

Samples (10 replicates per tissue age) were taken from 3, 6, 12 and 24-month-old ETs of cell line 1537-1, 10 days after subculturing on fresh maintenance medium, and then made into cell suspensions. Briefly, $20 \mu \mathrm{L}$ suspension was transferred to a slide, stained with $1 \% \mathrm{w} / \mathrm{v}$ acetocarmine for 30 s, then with Evans blue (Gaff and Okong'o-Ogola 1971). A cover glass was placed on the slide and the slide washed. The samples were observed with a stereomicroscope (Stemi 508 , Germany) for stereological analysis.

\section{Determination of intracellular substances}

ETs $(2 \mathrm{~g})$ from cell line $1537-1$ were ground at $4{ }^{\circ} \mathrm{C}$ in $1.8 \mathrm{~mL}$ of $100 \mathrm{mM}$ cool phosphate buffer ( $\mathrm{pH} 7.4$ ), supplemented with $1 \mathrm{mM}$ EDTA and $2 \% \mathrm{w} / \mathrm{v}$ ) polyvinylpyrrolidone polymer (PVPP). The mixtures were then centrifuged at $10,000 \times g$ for $10 \mathrm{~min}$. The supernatant was used to estimate activity of superoxidase (SOD), peroxidase (POD) and catalase (CAT). Three replicates were prepared to assay each enzyme.

SOD activity was assayed using $200 \mu \mathrm{L}$ of the extract in $4 \mathrm{~mL}$ of reagent containing $50 \mathrm{mM}$ phosphate buffer $(\mathrm{pH}$ 7.4), $0.1 \mathrm{mM}$ EDTA, $10 \mu \mathrm{M}$ nitroblue-tetrazolium (NBT), $10 \mathrm{mM} 1-$ methionine, and $0.001 \mathrm{mM}$ riboflavin. After $0.5 \mathrm{~min}$, absorbance was measured at $560 \mathrm{~nm}$ for $10 \mathrm{~min}$. One SOD enzyme unit was defined as the quantity of SOD required to produce a $50 \%$ inhibition in the reduction of NBT. SOD activity was expressed as units per milligram protein per gram FW. SOD activity was assayed as described by Beauchamp and Fridovich (1971).

POD activity was measured as described by Britton and Maehly (1955). The $200 \mu \mathrm{L}$ extract added in $3 \mathrm{~mL}$ of the reaction solution which containing guaiacol $(50 \mathrm{mM})$, $50 \mathrm{mM}$ phosphate buffer ( $\mathrm{pH} 6.8), \mathrm{H}_{2} \mathrm{O}_{2}(2 \%)$. After $0.5 \mathrm{~min}$, absorbance at $470 \mathrm{~nm}$ was measured for $4 \mathrm{~min}$. One unit of enzyme was expressed as $\mu$ moles per milliliter of $\mathrm{H}_{2} \mathrm{O}_{2}$ reduced per minute.
CAT activity was measured as described by Bergmeyer (1970). The reaction mixture $(3 \mathrm{~mL})$ contained $200 \mu \mathrm{L}$ extract, $50 \mathrm{mM}$ phosphate buffer (pH 7.0) with $0.001 \mathrm{M}$ EDTA and $\mathrm{H}_{2} \mathrm{O}_{2}(3 \% \mathrm{w} / \mathrm{v})$. After $0.5 \mathrm{~min}$, absorbance at $240 \mathrm{~nm}$ was recorded for 4 min to determine the amount of $\mathrm{H}_{2} \mathrm{O}_{2}$ reduced per minute. One unit of CAT activity was defined as one $\mu$ mole $\mathrm{H}_{2} \mathrm{O}_{2}$ destroyed per minute.

Starch and endogenous soluble sugars were measured using a phenol-sulfuric acid method (Dubois et al. 1956). Samples of $2 \mathrm{~g}$ (with three replicates) were ground in deionized water, then centrifuged at $10,000 \times g$ for $15 \mathrm{~min}$ at $4{ }^{\circ} \mathrm{C}$. The pellet was dried, weighed and heated for $10 \mathrm{~min}$. The supernatants were treated with $5 \% \mathrm{v} / \mathrm{v}$ phenol and $98 \% \mathrm{v} / \mathrm{v}$ sulfuric acid, and absorbance at $485 \mathrm{~nm}$ was recorded.

Total soluble proteins were measured using the Bradford (1976) method; $2 \mathrm{~g}$ callus (three replicates) was ground with $1.5 \mathrm{~mL}$ phosphate buffer $(\mathrm{pH} 7.0)$, then centrifuged at $10,000 \times g$ for $10 \mathrm{~min}$ at $4{ }^{\circ} \mathrm{C}$. The supernatant was discarded, and the pellet was washed with acetone, then dissolved in $1.0 \mathrm{~mL}$ of $0.1 \mathrm{M} \mathrm{NaOH}$. Absorbance was then measured at $595 \mathrm{~nm}$.

\section{Maturation experiment 2: genotype, tissue age and proliferation rate}

The effects of genotype, tissue age and proliferation rate on the production of SEs were evaluated using cell lines from seed families 36, 37 and 39 of pine wood nematode-resistant $P$. thunbergii.and analyzing the mature SEs produced on the maturation medium.

The effects of genotypes on SEP were analyzed using $2 \mathrm{~mL}$ of a cell suspension (approximately $500 \mathrm{mg} \mathrm{FW}$ ) generated from approximately 6-month-old ETs of the respective cell lines and transferred to the maturation medium. Four replicates were prepared per genotype.

For determining proliferation rates, two cell lines (1537-1 and 1637-2) with the highest SEP initiated in 2015 and 2016, respectively, were mainly experimented. Fresh ET (1 g FW on maintenance medium) from 3-, 6-, 12-, 15-, 18-, 21and 24-month-old ETs was transferred onto the maintenance medium, with four replicates per culture age. The ETs were subcultured on maintenance medium every 2 weeks. The proliferation rate was determined after 2 weeks.

For analyzing the effect of tissue age (the total culture time of ETs on maintenance medium) on SEP, the two cell lines (1537-1 and 1637-2) with the highest SEP initiated in 2015 and 2016, respectively, were mainly used. A 2-mL cell suspension of each cell line was generated from 3-, 6-, 12-, 15-, 18-, 21- and 24-month-old ETs and transferred to the maturation medium. Four replicates were prepared per culture age. The number of mature SEs was recorded for each line after 10 weeks. 


\section{Statistical analyses}

SEP after the various treatments was evaluated using an ANOVA and Pearson's correlation coefficients. Means were compared using Duncan's multiple range test with significance set at $p<0.05$. All analyses were done using SPSS version 19 (IBM, Armonk, NY, USA) and R version 3.6.0 with the R stats package (R Core Team, 2019). The proliferation rate (fold-change) was defined as (FW at the end of treatment $-\mathrm{FW}$ at the start of treatment)/FW at the start of treatment. The SEP was defined as the number of mature SEs on maturation medium /the FW of ETs transferred from the proliferation to maturation medium. The FW of ETs transferred from the proliferation to maturation medium was calculated as the mass of the filter containing the tissues ( $2 \mathrm{~mL}$ suspension culture) - the mass of the filter ( $2 \mathrm{~mL}$ liquid medium). The data from cell line 1537-1, which had the greatest production, was used to calculate Pearson's correlation coefficients for tissue ages (3-, 6-, 12- and 24-month-old), soluble sugar, starch, soluble protein, enzymatic activity (SOD, POD and CAT), proliferation rate and SEP.

Fig. 1 Morphology and histological features of embryogenic cells with tissue age of Pinus thunbergii. a-l: Embryonic tissue (ET) subcultures at, $\mathbf{a}-\mathbf{c}$ 3 months; $\mathbf{d}-\mathbf{f}$ at 6 months; $\mathbf{g}-\mathbf{i}$ at 12 months; $\mathbf{j}-\mathbf{l}$ at 24 months
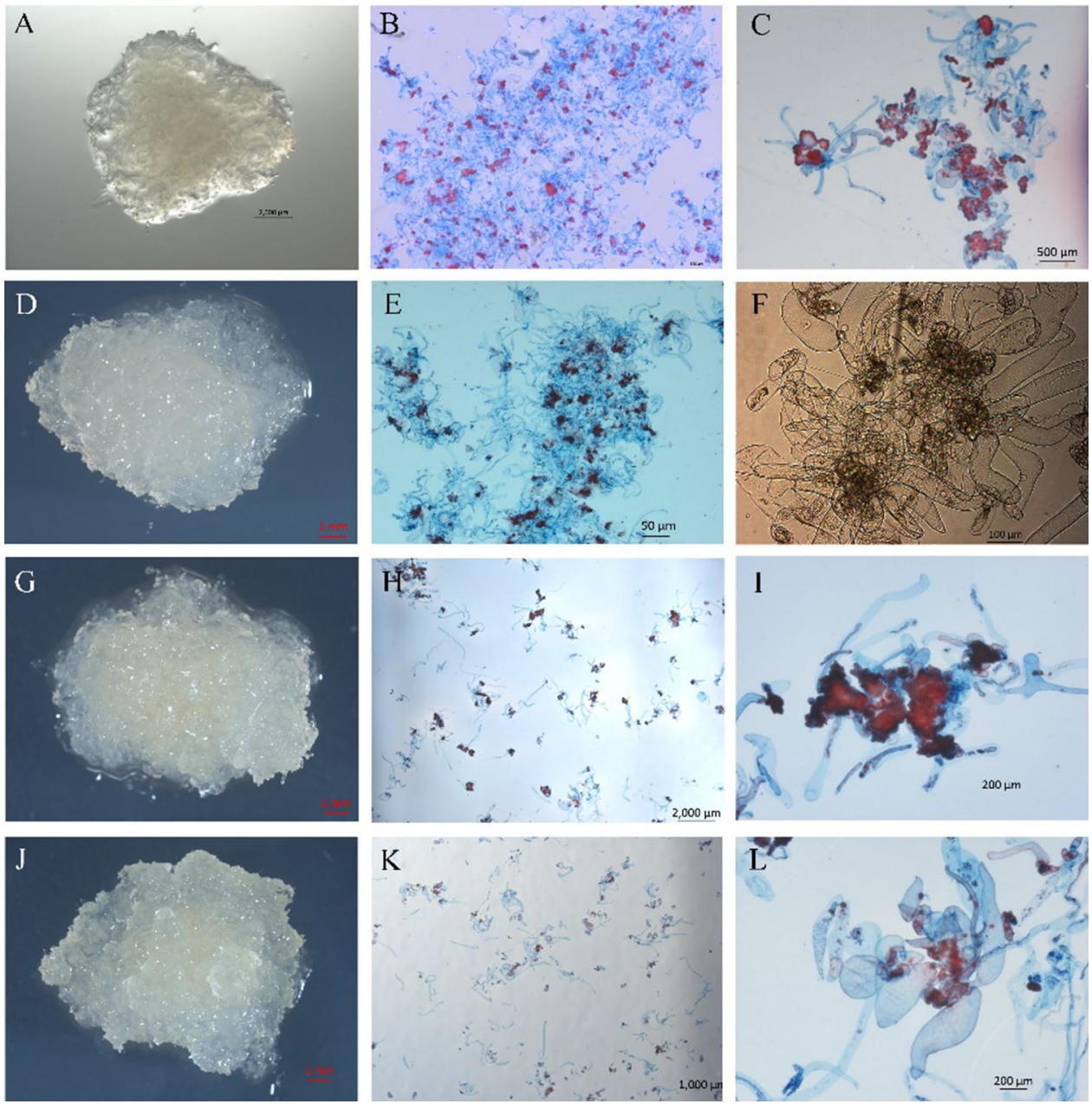

\section{Morphological development and physiological variations in $P$. thunbergii embryogenic cells}

During 3 months of subculturing on maintenance medium, the filamentous and protuberant surfaces of the clumps were visible, and the ET surface was transparent and glossy (Fig. 1a). After double staining by Evans blue and acetocarmine, we found most cell types had early somatic embryonic features (embryonal suspensor mass, ESM) (Fig. 1b, c). After 6 months of subculturing, the ET transparency decreased, and the filamentous and protuberant surfaces of the clumps were reduced; however, the ET surface was still glossy (Fig. 1d). The ET still showed early somatic embryo-associated features (Fig. 1e, f). At 12 months, the filamentous and protuberant surfaces of the clumps rarely appeared, and the ET became nontransparent (Fig. 1g). In addition, a gradual decrease was observed in the red area when using acetocarmine staining, and abnormal cells were present (Fig. 1h, i). By 24 months, the filamentous and protuberant surfaces of 
the clumps had disappeared (Fig. 1j), and the proportions of red areas and acetocarmine staining were significantly reduced (Fig. 1k); Further observations revealed that the consistency in cell morphology was low, as was the proportion of cells having early SE structures. Moreover, the number of abnormal cells, such as cylindrical and oval cell types, increased (Fig. 11). The emergence of abnormal cells indicated that the embryogenic capacity of the ET had declined. In general, the ETs were young and vigorous for up to 6 months. However, by 12 months, the filamentous and protuberant surfaces of the clumps had disappeared, and the acetocarmine-stained areas and the proportion of ESMs had decreased.

In a further study of cellular physiology, the intracellular substances (soluble sugar, starch and soluble protein) $(p<0.001)$ and enzymatic activities (SOD, POD and CAT) $(p<0.001)$ differed significantly among the tissue ages (Fig. 2). The trends in soluble sugar and soluble protein were similar, first increasing and then decreasing with tissue age, and both peaked at 6 months. However, starch content increased from $27.1 \mathrm{ng} \mathrm{g}^{-1} \mathrm{FW}$ at 3 months to $537.1 \mathrm{ng} \mathrm{g}^{-1} \mathrm{FW}$ at 24 months (Fig. 2a). Among the enzymatic activities, CAT activity increased from 27.6 $\mathrm{U} \mathrm{g}^{-1} \mathrm{FW}$ at 3 months to $47.7 \mathrm{U} \mathrm{g}^{-1} \mathrm{FW}$ at 12 months, then dropped to $36.7 \mathrm{U} \mathrm{g}^{-1} \mathrm{FW}$ at 24 months. In contrast, the POD activity showed a decreasing trend from $70.2 \mathrm{U}$ $\mathrm{g}^{-1} \mathrm{FW}$ at 3 months to $50.3 \mathrm{U} \mathrm{g}^{-1} \mathrm{FW}$ at 6 months, then increased with tissue age. SOD activity did not differ significantly between 3 and 6 months, but it had increased significantly by 24 months (Fig. 2b). We found that cell morphology responded to variations in intracellular substances and enzyme activities as the tissue aged.

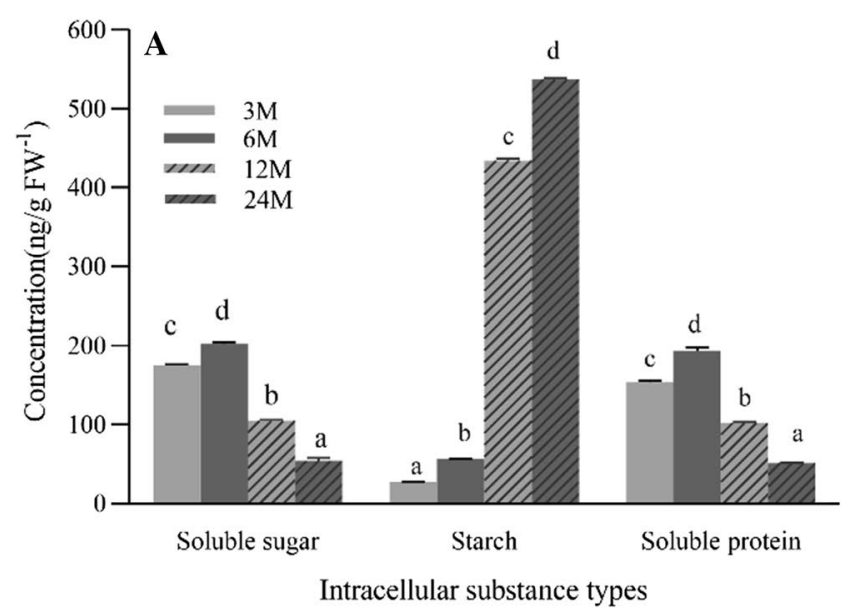

Fig. 2 Mean $( \pm S E)$, a concentration of intracellular metabolites and b activity of enzymes from tissues of Pinus thunbergii at different age (3-24 months [M]). Different lowercase letters above the bars for an

\section{Effects of maternal genotype, tissue age and proliferation rate on the SEP of $P$. thunbergii}

SEP was significantly $(p<0.001)$ affected by genotype, tissue age and proliferation rate (Figs. 3, 4). In seed family 36, SEP varied from 58 to 182 mature SEs per gram FW, and in seed family 37, the SEP varied from 354 to 1983 mature SEs per gram FW. Thus, the maternal genotypes appeared to determine the SEP level, and the SEP varied among established cell lines having the same maternal genotype. Additionally, in tests of cell lines initiated in 2015 and 2016, the highest SEP was obtained in cell line 1537-1 and 1637-2, respectively (Fig. 3a, b). The SEP and proliferation rate trends with tissue age were similar, especially in the highyielding cell lines (Fig. 4). Thus, in cell line 1537-1, both the SEP and proliferation rate increased from 3 to 6 months, and then, they decreased along with tissue age (up to 24 months) (Fig. 4a). However, in cell line 1637-2, SEP increased from 3 to 6 months, but the proliferation rate decreased (Fig. 4b). In addition, in the rest of the cell lines, the proliferation rates all decreased with tissue age. At 24-months, the proliferation rates maintained an approximately onefold increase. Although the SEP increased from 3 to 6 months in some cell lines, it decreased or lost the maturation capacity from 6 to 24 months (Electronic supplementary material Fig. S1). In general, the SEP and proliferation rate trends decreased as the tissue age increased.

In addition, the interactions among genotypes, tissue age, proliferation rate and SEP showed that a high SEP was obtained in cell lines $1539-1$ and $1537-1$ at 3-6 months, when the proliferation rate was $\geq$ threefold. When the tissue was 9-12 months old, the proliferation rate dropped to 2-threefold, and the SEP ranged from 1,762 to 86 SEs per gram FW. Moreover, when the tissue was 12-24 months old,

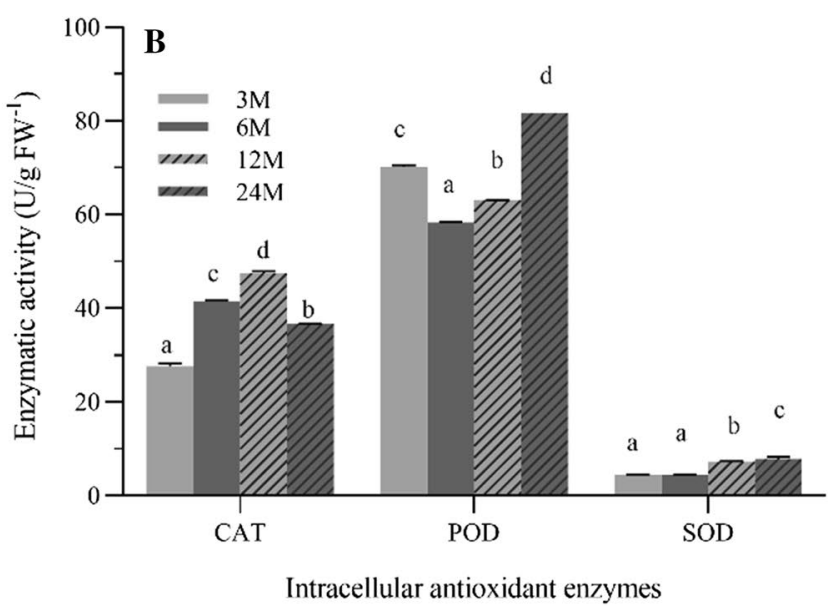

indicator indicate a significant difference $(p<0.001)$ at the tissue ages using Duncan's test. CAT: catalase 


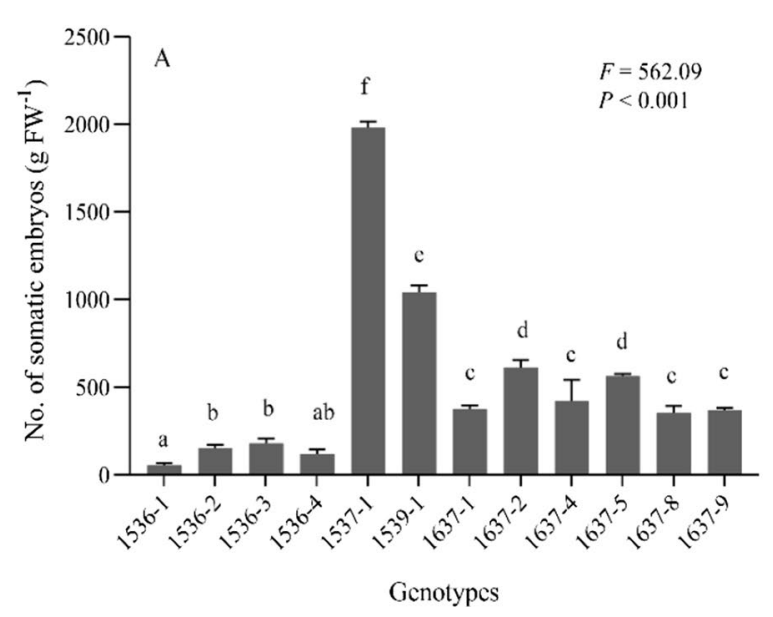

Fig. 3 Somatic embryo production by Pinus thunbergii. a Mean number $( \pm \mathrm{SE})$ of somatic embryos produced by each genotype. b Somatic embryos produced by the most prolific cell line, 1537-1.

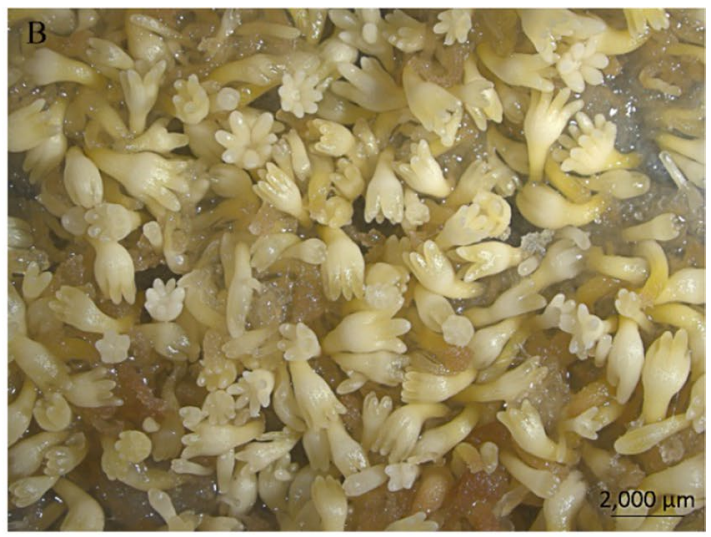

Different lower case letters above the bars indicate a significant difference in number produced by genotypes $(p<0.05)$ in Duncan's test. Four replicates were prepared per cell lines

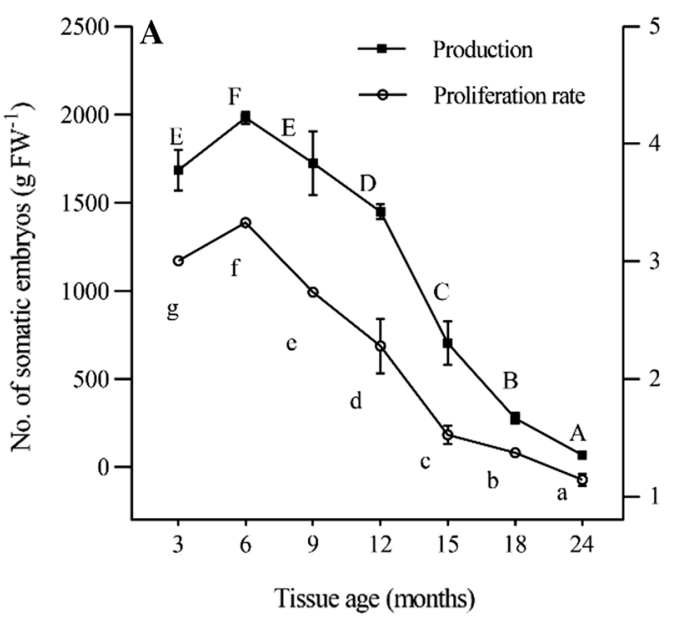

Fig. 4 Mean number $( \pm$ SE) of somatic embryo produced and proliferation rate of embryonic tissue (ET) by cell lines, a 1537-1 and b 1637-2 at different tissue ages of Pinus thunbergii. Different lower case letters indicate a significant difference at a tissue age, different

the proliferation rate dropped to 1-1.9 fold, and the SEP ranged from 704 to 0 SEs per gram FW (Fig. 5). At this time, some cell lines lost the capability to produce SEs. We found that although SEP differed among the genotypes, a higher SEP was easy to obtain from young ETs (3-6 months old), especially when the proliferation rate was $\geq$ threefold.

\section{Correlation analysis of SEP in $P$. thunbergii}

We determined the differences in SEP between maternal genotypes and cell lines, and we found that line 1537-1 had the highest SEP among the tested cell lines. The relationships

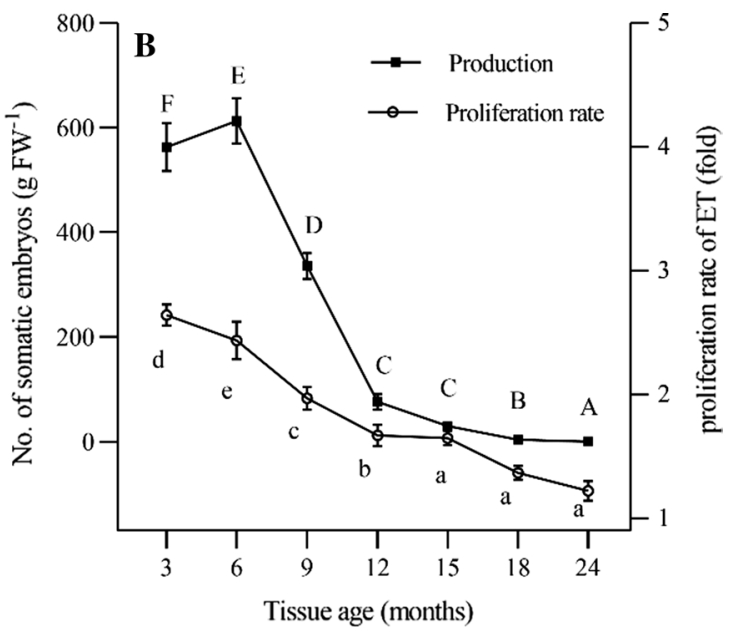

upper case letters indicate a significant difference in production at a tissue age $(p<0.001$; Duncan's test). Four replicates were prepared per cell lines

between the high-yielding SEs and cell physiological changes (soluble sugar, starch, soluble protein and enzyme activity) were studied. A correlation analysis showed that the SEP was positively correlated with soluble sugar and protein, but negatively correlated with starch. SOD and POD activities, however, had a significantly negative correlation with SEP, but CAT was not correlated with SEP. The relationships among enzyme activity levels showed the CAT was positively correlated with SOD, but negatively correlated with POD. Thus, the influence of CAT on SEP might be reduced by the counter-effect. Moreover, SEP was positively correlated with proliferation rate, but negatively correlated 
Fig. 5 Relationship of proliferation rate, tissue age, genotype (cell line) and somatic embryo production for Pinus thunbergii. On the dashed line from Cell line, 36-n represents 1536-1, 1536-2, 1536-3, and 1536-4; $37-n$ represents $1537-1$, $1637-1,1637-2,1637-4$, $1637-5,1637-8$, and 1637-9. The number on the solid lines indicates the proliferation rate (fold). The number on the dotted lines from Tissue age is the subculturing time (months). The number on the dotted lines from Cell line is the code of the tested cell lines

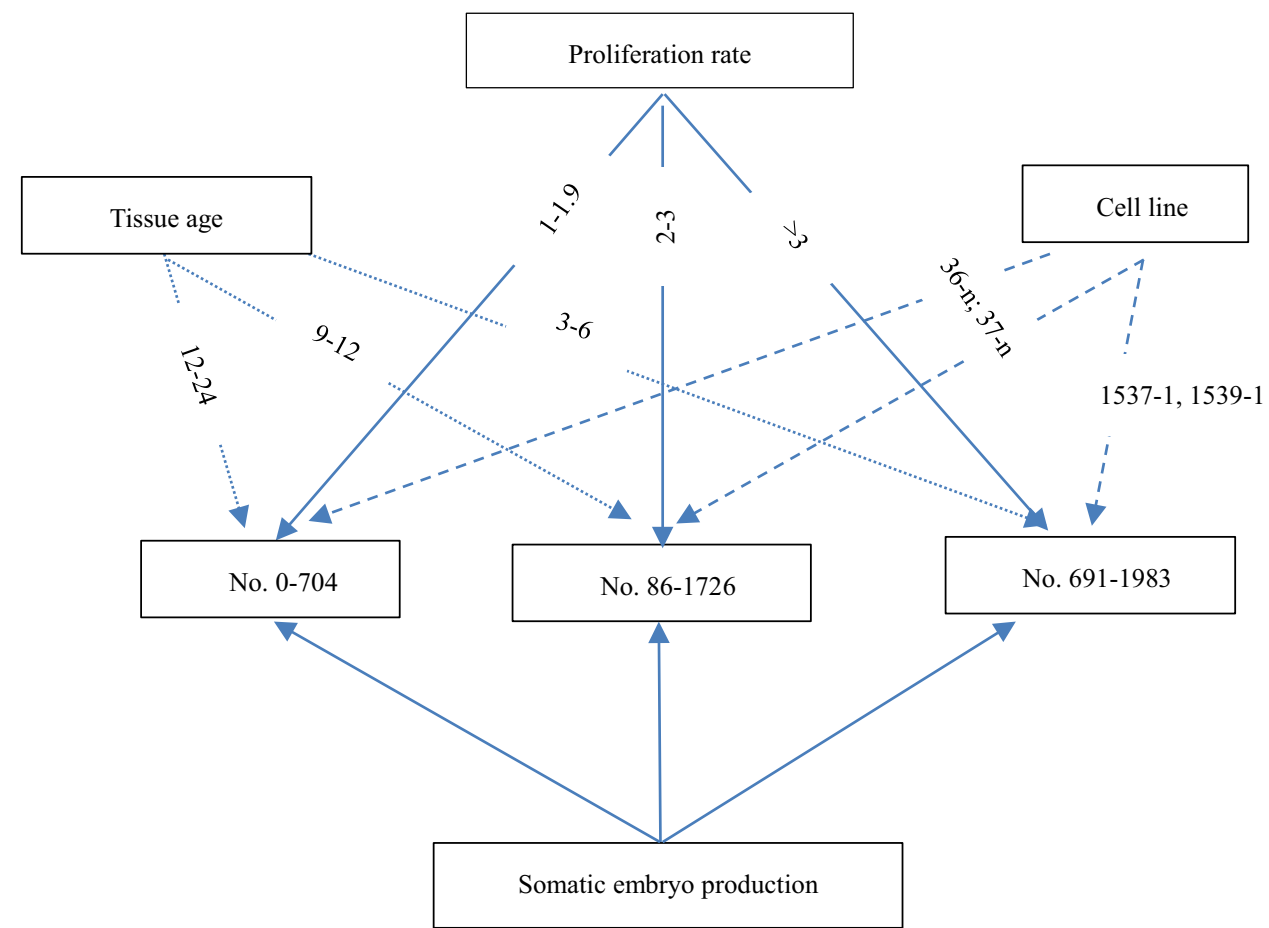

with the tissue age. We found that starch was negatively correlated with soluble sugar, soluble protein and proliferation rate, but positively correlated with tissue age, while tissue age was negatively correlated with SEP (Fig. 6). The starch interactions showed that starch accumulation during the proliferation stage was adversely related to the SEP production

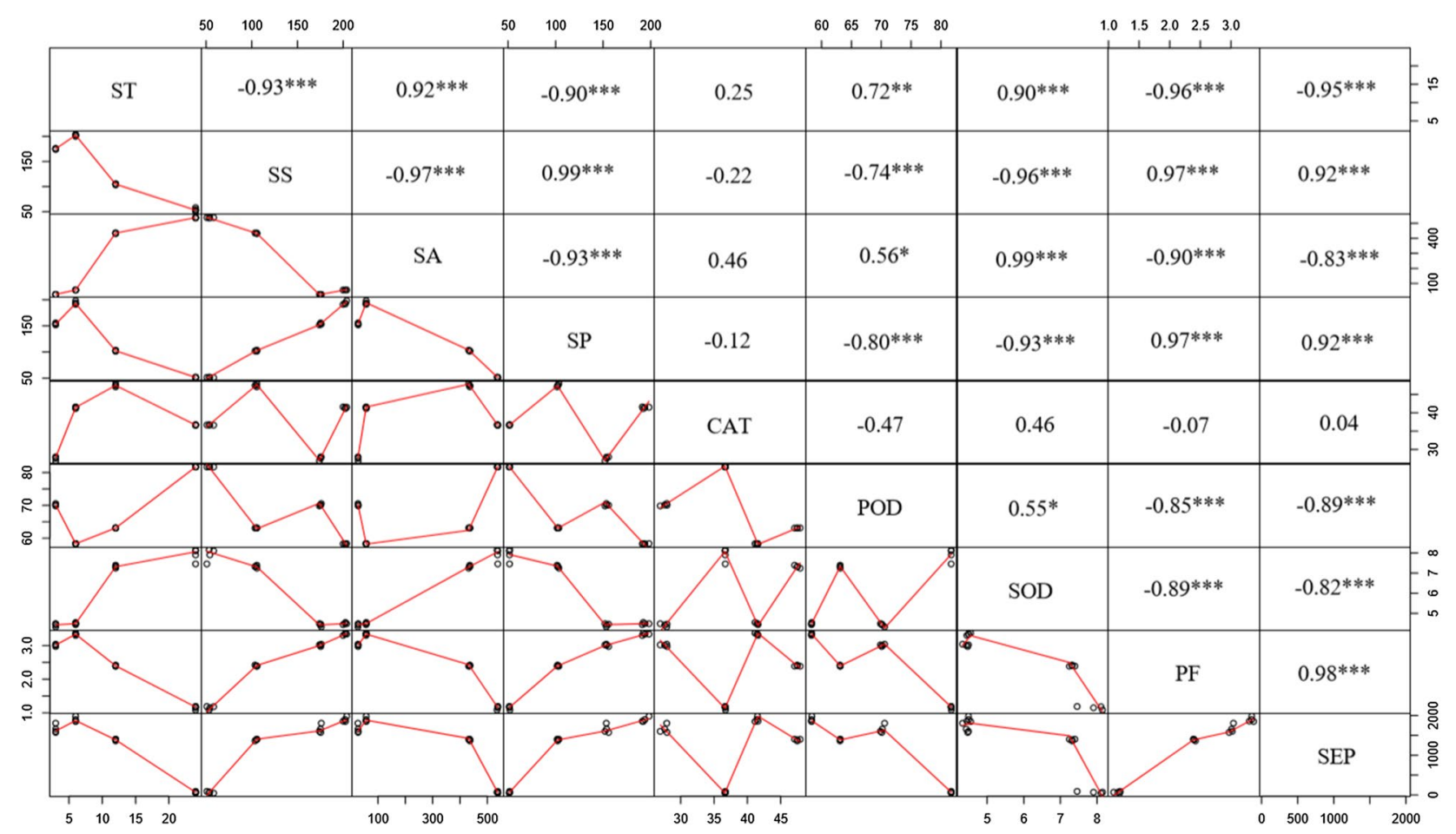

Fig. 6 Correlation analysis of somatic embryo production by the most prolific cell line, 1537-1. ST, tissue age; SS, soluble sugar; SA, starch; SP, soluble protein; CAT, catalase; POD, peroxidase;
SOD, superoxide dismutase; PF, propagation frequency; SEP, somatic embryo production. Significant differences for each variable: $* p<0.05, * * p<0.01, * * * p<0.001$ 
of ETs. In addition, the decreases in soluble sugar, soluble protein and proliferation rate reflected the ET maturation capacity to some extent.

\section{Discussion}

\section{Effects of cell morphology and physiology on SEP in $P$. thunbergii}

Observations of tissue morphology indicated that subculturing for 6 months was a key factor. At this time, although the ET transparency decreased, and filamentous and protuberant surfaces of the clumps were reduced, further microscopic observations revealed that the proportion of the acetocarmine-stained red area changed little, and most of the cell types were still morphologically young (ESM). Meanwhile, SEP in P. thunbergii peaked. Similar results were reported in Scots pine (Abrahamsson et al. 2012). However, after 6 months of subculturing, the filamentous and protuberant surfaces of ET disappeared gradually, the proportion of the acetocarmine-stained red area was replaced with abnormal cells, and SEP decreased accordingly. We considered that the disappearance of filamentous and protuberant surfaces of ETs might indicate the beginning of ET aging. The degeneration of the ET morphology led to a decrease in SEP in Picea abies (Filonova 2000). We, therefore, hypothesized that the ET maturation capacity of $P$. thunbergii could be estimated by ET surface morphology, histological features, and the proportion of the acetocarmine-stained red areas during the proliferation stage. We found that the CAT activity and intracellular substance (soluble protein, soluble sugar and starch) levels increased when tissues were 6 months old, when SEP peaked. As for the degeneration of ET morphology at 6 months, as mentioned above, the decrease in ET transparency might be related to the increases in intracellular substances. In addition, although the filamentous and protuberant surfaces of the clumps were declining, the ETs still showed ESM structures and the highest proportions of acetocarmine-stained red areas. We speculated that the increase in SEP might be related to the increase in intracellular substance levels and enzymatic activities at this point in time. Grzyb et al. (2017) found that intracellular substances (especially soluble sugar) regulate the transport of phytohormones and the expression of phytohormone response pathways. Pacholczak et al. (2005) also found a correlation between soluble sugars and both endogenous indole-3-acetic acid and abscisic acid levels. In addition, our study found that ETs having lower levels of SOD and POD had good maturation capacities. Diehn et al. (2009) also demonstrated that totipotent cells contain lower levels of reactive oxygen. These factors may serve as suitable markers for assessing the ET maturation capacity during the proliferation stage under favorable maturation conditions. This approach provides novel insights into early events that influence the ET maturation capacity in somatic embryogenesis of $P$. thunbergii resistant to the pine wood nematode.

\section{Effects of maternal genotype, tissue age and proliferation rate on SEP in $P$. thunbergii}

SEP was significantly $(p<0.001)$ affected by maternal genotype, tissue age and proliferation rate. The genotypedepended SEs maturation and the considerable variations in SEP among cell lines had been reported previously (Montalban et al. 2010, 2012; Kim and Moon 2014; Salaj et al. 2019). Here, we determined that if the clone was productive, then the original maternal genotypes might have a greater potential to produce high-yielding SEs than other maternal genotypes. Thus, the cell lines from seed family $37 \mathrm{had}$ higher SEP levels than those from seed family 36 . This result further confirmed the decisive influence of maternal genotypes on SEP. The acquisition of ETs with high-yielding SEs may be correlated with the explant genotype (megagametophyte). Because the seed orchard was open-pollinated, the maternal genes were the same, but the paternal genes were different, which may explain the lack of ETs that produced high-yielding SEs in 2016. Mee et al. (2016) also found that genetic background had a great influence on SEP. The regular SEP level in maternal and clonal genotypes may be an important basis when selecting for the mass propagation of elite clonal genotypes.

In addition, SEP and proliferation rate tended to decrease as tissue age increased were identified. The degeneration of embryogenic potential with increasing tissue age is a common phenomenon in Pinus species (Wang et al. 2019; Yang et al. 2020). However, assessing SEP by tissue age alone is not accurate, because the degree of ET degeneration is different among genotypes and culture conditions. For example, cucumber (Cucumis sativus L.) maintains its embryogenic potential for more than 3.5 years in cytokininindependent suspension cultures (Andryskova et al. 2009). Our results suggested the combination of ET surface morphology, histology (the proportion of the acetocarminestained red area) and variations in physiological characteristics (carbohydrates and enzymatic activities) could be used to precisely assess the ET maturation capacity. In general, young ETs were better choices for SEP than tissues used for long-term maintenance (von Aderkas et al. 2003; Breton et al. 2006; Lelu-Walter and Paques 2009; Park et al. 2011). Moreover, the interactions among maternal genotypes, tissue ages and proliferation rates of $P$. thunbergii showed that the high-yielding SEs occurred at a proliferation rate of more than threefold, when tissues were 6 months old for cell lines 1537-1 and 1539-1. We determined that specific maternal genotypes, young cultures (less than 6 months old) and high 
proliferation rates (threefold) are necessary for high yields of SEs. Additionally, the SEP was genotype-dependent when the latter two conditions were met. Thus, there is increasing evidence that SEP is genotype-dependent.

\section{Conclusions}

Our results showed that SEP was significantly affected by maternal genotype $(p<0.001)$, tissue age $(p<0.001)$ and proliferation rate $(p<0.001)$. The maternal genotype determined the level of SEP, and the tissue age similarly influenced the proliferation rate and SEP, in which both were reduced as tissue age increased. In addition, a high proliferation rate ( $>$ threefold) might be beneficial to the production of SEs. Moreover, during the proliferation stage, the ET's morphological evolution also showed that decreases in transparency and filamentous surfaces of ETs, as well as the proportion of acetocarmine-stained red areas, decreased along with SEP. The ET morphology and histology may reflect the SEP capability to some extent. Additionally, a correlation analysis showed that SEP was positive correlated with proliferation rate, soluble sugar and protein, but negatively correlated with tissue age, starch, SOD and POD. In general, the ET maturation capacity of pine wood nematode-resistant $P$. thunbergii may be estimated using maternal genotypes, proliferation rate, tissue age, ET surface morphology, histology, as the proportion of acetocarmine-stained red areas, and the variation among physiological characteristics (carbohydrates and enzymatic activities). This study provides new insights for assessing the ET maturation capacities accurately during the proliferation stage of Pinus species, especially pine wood nematode-resistant $P$. thunbergii.

Open Access This article is licensed under a Creative Commons Attribution 4.0 International License, which permits use, sharing, adaptation, distribution and reproduction in any medium or format, as long as you give appropriate credit to the original author(s) and the source, provide a link to the Creative Commons licence, and indicate if changes were made. The images or other third party material in this article are included in the article's Creative Commons licence, unless indicated otherwise in a credit line to the material. If material is not included in the article's Creative Commons licence and your intended use is not permitted by statutory regulation or exceeds the permitted use, you will need to obtain permission directly from the copyright holder. To view a copy of this licence, visit http://creativecommons.org/licenses/by/4.0/.

\section{References}

Abrahamsson M, Valladares S, Larsson E, Clapham D, von Arnold S (2012) Patterning during somatic embryogenesis in Scots pine in relation to polar auxin transport and programmed cell death. Plant Cell Tiss Organ Cult 109:391-400
Andryskova L, Reinohl V, Klem M, Prochazka S (2009) Long-term suspension cultures of cucumber (Cucumis sativus L.) with high embryogenic potential. Acta Physiol Plant 31(4):675-681

Beauchamp C, Fridovich I (1971) Superoxide dismutase: improved assays and an assay applicable to acrylamide gels. Anal Biochem 44:276-287

Bergmeyer HU (1970) Methoden der enzymatischen analyse. Arch Der Pharm 295:863-864

Bradai F, Pliego-Alfarom F, Sanchez-Romero C (2016) Long-term somatic embryogenesis in olive (Olea europaea $L$.): influence on regeneration capability and quality of regenerated plants. Sci Hortic 199:23-31

Bradford MMA (1976) A rapid and sensitive method for quantitation of microgram quantities of protein utilizing the principle of protein-dye binding. Anal Biochem 25(1):248-256

Breton D, Harvengt L, Trontin JF, Bouvet A, Favre JM (2005) High subculture frequency, maltose-based and hormone-free medium sustained early development of somatic embryos in maritime pine. Vitro Cell Dev Biol-Plant 41:494-504

Breton D, Harvengt L, Trontin JF, Bouvet A, Favre JM (2006) Longterm subculture randomly affects morphology and subsequent maturation of early somatic embryos in maritime pine. Plant Cell Tissue Organ Cult 87:95-108

Britton C, Maehly AC (1955) Assay of catalase and peroxidase. In: Packer Lester (ed) Methods in Enzymology, 2nd edn. Academic Press, New York

Carneros E, Toribio M, Celestino C (2017) Effect of ABA, the auxin antagonist $\mathrm{PCIB}$ and partial desiccation on stone pine somatic embryo maturation. Plant Cell Tiss Organ Cult 131:445-458

Diehn M, Cho RW, Lobo NA, Kalisky T, Dorie MJ, Kulp AN, Qian D, Lam JS, Ailles LE, Wong M, Joshua B, Kaplan MJ, Wapnir I, Dirbas FM, Somlo G, Garberoglio C, Paz B, Shen J, Lau SK, Quake SR, Brown JM, Weissman IL, Clarke MF (2009) Association of reactive oxygen species levels and radio resistance in cancer stem cells. Nature 458(7239):780-783

Dubois M, Gilles KA, Hamilton JK, Reberts PA, Smith F (1956) Colorimetric method for determination of sugars and related substances. Anal Chem 28:350-356

Filonova LH (2000) Developmental pathway of somatic embryogenesis in Picea abies as revealed by time-lapse tracking. J Exp Bot 51:249-264

Finkelstein R, Reeves W, Ariizumi T, Steber C (2008) Molecular aspects of seed dormancy. Annu Rev Plant Biol 59:387-415

Gaff DF, Okong' O-Ogola O (1971) The use of non-permeating pigments for testing the survival of cells. J Exp Bot 22:756-758

Gahan PB, George EF (2008) Adventitious regeneration. In: George EF, Hall MA, De Klerk GJ (eds) Plant Propagation by Tissue Culture, 3rd edn. Springer, Dordrecht, pp 355-401

Godel-Jedrychowska K, Kulinska-Lukaszek K, Horstman A, Soriano M, Li M, Malota K, Boutilier K, Kurczynska EU (2020) Symplasmic isolation marks cell fate changes during somatic embryogenesis. J Exp Bot 71(9):2612-2628

Grzyb M, Kalandyk A, Waligorski P, Mikula A (2017) The content of endogenous hormones and sugars in the process of early somatic embryogenesis in the tree fern Cyathea delgadii Sternb. Plant Cell Tiss Organ Cult 129(3):387-397

Gupta PK, Durzan DJ (1987) Biotechnology of somatic polyembryogenesis and plantlet regeneration in loblolly pine. Bio Technol 5:147-151

Gupta PK, Durzan DJ (1985) Shoot multiplication from mature trees of Douglas-fir (Pseudotsuga menziesii) and sugar pine (Pinus lambertiana). Plant Cell Rep 4(4):177-179

Herve E, Benoit B, Frederic G (2013) Development of coffee somatic and zygotic embryos to plants differs in the morphological, histochemical and hydration aspects. Tree Physiol 33:640-653 
Jain SM, Gupta PK (2018) Step wise protocols for somatic embryogenesis of important woody plants, vol 1 . Springer, Cham

Jones NB, van Staden J (2001) Improved somatic embryo production from embryogenic tissue of Pinus patula. Vitro Cell Dev Biol Plant 37:543-549

Kim YW, Moon HK (2014) Enhancement of somatic embryogenesis and plant regeneration in Japanese red pine. Plant Biotechnol Rep $8: 259-266$

Klimaszewska K, Overton C, Stewart D, Rutledge RG (2011) Initiation of somatic embryos and regeneration of plants from primordial shoots of 10-year-old somatic white spruce and expression profiles of 11 genes followed during the tissue culture process. Planta 233:635-647

Krajnakova J, Haggman H, Gomory D (2009) Effect of sucrose concentration, polyethylene glycol and activated charcoal on maturation and regeneration of Abies cephalonica somatic embryos. Plant Cell Tissue Organ Cult 96:251-262

Lelu-Walter MA, Paques LE (2009) Simplified and improved somatic embryogenesis of hybrid larches (Larix $\times$ eurolepis and Larix $\times$ marschlinsii). Perspect breed Ann For Sci 66:104

Malik MQ, Mujib A, Gulzar B, Zafar N, Syeed R, Mamgain J, Ejaz B (2020) Genome size analysis of field grown and somatic embryo regenerated plants in Allium sativum L. J Appl Genet 61(12):25-35

Maruyama TE, Hosoi Y (2016) Somatic embryogenesis and plant propagation in Japanese black pine (Pinus thunbergiiParl.) and Japanese red pine (Pinus densifloraZieb. et Zucc.). In: Park YS, Bonga JM, Moon HK (eds) Vegetative propagation of forest trees. NIFOS, Seoul, pp 623-638

Maruyama E, Hosoi Y, Ishii K (2005) Somatic embryo production and plant regeneration of Japanese black pine (Pinus thunbergii). J For Res 10:403-407

Mee JK, Dong JA, Ki BM, Hye SC, Sung RM, Jung HS, Jae HJ, Hyun SK (2016) Highly efficient plant regeneration and Agrobacteriummediated transformation of Helianthus tuberosus L. Ind Crops Prod 83:670-679

Montalban IA, De Diego N, Moncalean P (2010) Bottlenecks in Pinus radiata somatic embryogenesis: improving maturation and germination. Trees Struct Funct 24:1061-1071

Montalban IA, de Diego N, Moncalean P (2012) Enhancing initiation and proliferation in radiata pine (Pinus radiata $\mathrm{D}$. Don) somatic embryogenesis through seed family screening, zygotic embryo staging and media adjustments. Acta Physiol Plant 34:451-460

Pacholczak A, Szydło W, Lukaszewska A (2005) The effect of etiolation and shading of stock plants on rhizogenesis in stem cuttings of Cotinus coggygria. Acta Physiol Plant 27:417-428

Park SY, Cho HM, Moon HK, Kim YW, Paek KY (2011) Genotypic variation and aging effects on the embryogenic capability of Kalopanax septemlobus. Plant Cell Tiss Organ Cult 105:265-270

R Core Team (2019) R: A Language and Environment for Statistical Computing. R for Statistical Computing, Vienna. https://www.RProject.org
Ramarosandratana A, Harvengt L, Bouvet A, Calvayrac R, Paques M (2001) Influence of the embryonal-suspensor mass (ESM) sampling on development and proliferation of maritime pine somatic embryos. Plant Sci 160(3):473-479

Salaj T, Klubicova K, Matusova R, Salaj J (2019) Somatic embryogenesis in selected conifer trees Pinus nigra Arn and Abies hybrids. Front Plant Sci 10:13

Song Y, Li SJ, Bai XM, Zhang HG (2018) Screening and verification of the factors influencing somatic embryo maturation of Larix olgensis. J Forest Res 29:1581-1589

Sun TY, Ye JR, Wu XQ, Zhu LH, Wu J, Liang F (2015) Induction of Embryonic Callus from Pinus thunbergii for resistance to pine wilt disease. J Northeast For Univ 9:98-101 ((in Chinese))

Sun TY, Wang YL, Shen LY, Wu XQ, Zhu LH, Ye JR (2019a) Impact of medium components on somatic embryo maturation in Pinus thunbergii. Sci Silvae Sin 55(4):178-186 ((in Chinese))

Sun TY, Wang YL, Zhu LH, Wu XQ, Ye JR (2019b) Plant regeneration by somatic embryogenesis in Pinus thunbergii resistant to the pine wood nematode. Can J For Res 49(12):1604-1612

Vestman D, Larsson E, Uddenberg D, Cairney J, Clapham D, Sundberg E, von Arnold S (2010) Important processes during differentiation and early development of somatic embryos of Norway spruce as revealed by changes in global gene expression. Tree Genet Genomes 7(2):347-362

von Aderkas P, Pattanavibool R, Hristoforoglu K, Ma Y (2003) Embryogenesis and genetic stability in long term megagametophyte derived cultures of larch. Plant Cell Tiss Organ Cult 75:27-34

Wang YL, Sun TY, Shen LY, Wu XQ, Ye JR, Zhu LH (2019) Effects of subculture time on somatic embryogenesis of nematoderesistant Pinus thunbergii. J Southwest For Univ 39(2):78-85 ((in Chinese))

Yang F, Xia XR, Ke X, Ye JR, Zhu LH (2020) Somatic embryogenesis in slash pine (Pinus elliottii Engelm): improving initiation of embryogenic tissues and maturation of somatic embryos. Plant Cell Tiss Organ Cult 143:159-171

Yildirim T, Kaya Z, Işik K (2006) Induction of embryogenic tissue and maturation of somatic embryos in Pinus brutia TEN. Plant Cell Tiss Organ Cult 87(1):67-76

Zhang JW, Wang JH, Li QF, Ma JW (2014) Somatic embryogenesis of Picea asperata induced form immature embryos. Sci Silvae Sin 50(4):39-46 ((in Chinese))

Publisher's Note Springer Nature remains neutral with regard to jurisdictional claims in published maps and institutional affiliations. 